\title{
Perbedaan Kualitas Tidur Pasien Asma Terkontrol Sebagian pada Kategori Indeks Massa Tubuh (IMT)
}

\author{
Khalisah Atma Aulia $^{1}$, Reviono ${ }^{2}$, Ratih Dewi Yudhani ${ }^{3}$ \\ 1. Program Studi Kedokteran Fakultas Kedokteran, Universitas Sebelas Maret \\ 2. Bagian Paru RSUD Dr. Moewardi Surakarta \\ 3. Laboratorium Farmakologi Fakultas Kedokteran, Universitas Sebelas Maret
}

Korespondensi : khalisahatmabkl@gmail.com

\begin{abstract}
ABSTRAK
Pendahulun: Asma merupakan suatu penyakit saluran pernapasan karena adanya proses inflamasi kronik yang menyebabkan timbulnya gejala seperti wheezing, sesak napas, dada sesak dan batuk yang terjadi terutama pada malam hari atau menjelang pagi hari. Jumlah kasus asma di Jawa Tengah pada tahun 2013 sebesar 113.028 kasus. Gangguan pernapasan yang muncul dapat mengganggu aktivitas tidur sehingga menyebabkan menurunnya kualitas tidur seseorang. Selain itu, gangguan pernapasan saat tidur akan semakin berat apabila seorang penderita asma memiliki Indeks Massa Tubuh (IMT) yang tinggi seperti pada obesitas serta pada IMT yang terlalu rendah (kurus). Penelitian ini bertujuan untuk mengetahui perbedaan kualitas tidur pasien asma terkontrol sebagian pada kategori IMT.

Metode: Penelitian ini bersifat observasional analitik dengan pendekatan cross sectional. Penelitian dilakukan di Balai Besar Kesehatan Paru Masyarakat (BBKPM) Surakarta pada bulan Oktober - Desember 2018 dengan melibatkan 75 sampel. Pengumpulan data dilakukan melalui wawancara terpimpin dan pengukuran IMT. Data dianalisis secara statistik dengan uji Fisher's Exact Test.

Hasil: Hasil uji Fisher's Exact Test kualitas tidur pasien asma terkontrol sebagian pada kelompok IMT kurus dan normal adalah signifikan secara statistik $(\mathrm{p}=0,004)$, kelompok IMT normal dan gemuk signifikan secara statistik $(\mathrm{p}=0,013)$, serta kelompok IMT kurus dan gemuk tidak signifikan secara statistik $(\mathrm{p}=0,173)$.

Kesimpulan: Kualitas tidur baik lebih banyak terjadi pada pasien dengan IMT normal, sedangkan kualitas tidur buruk lebih banyak terjadi pada pasien dengan IMT kurus dan gemuk.
\end{abstract}

Kata Kunci: asma; kualitas tidur; indeks massa tubuh

\begin{abstract}
Introduction: Asthma is a respiratory disease due to a chronic inflammatory process that causes respiratory symptoms such as wheezing, shortness of breath, chest tightness and coughing that occurs mainly at night or early morning. The number of cases of asthma in Central Java in 2013 amounted to 113,028 cases. Breathing disorders that appear can interfere with sleep activities, causing a decrease in the sleep quality.In addition, breathing disorders during sleep will be more severe if an asthma sufferer has a high body mass index such as obesity and BMI that is too low (underweight). This study aims to determine the difference in sleep quality of partially controlled asthma patients in BMI category.

Methods: This research is an observational analytic study with a cross sectional approach. The study was conducted at Balai Besar Kesehatan Paru Masyarakat (BBKPM) Surakarta in October - December 2018 involving 75 samples. Data collection is done by conducting guided interviews and measuring patients' body mass index. Data were analyzed statistically by Fisher's Exact Test.

Results: Fisher's Exact Test results of the sleep quality of partly controlled asthma patients in the underweight and normal BMI group was statistically significant $(p=0.004)$, the normal
\end{abstract}


and overweight BMI group was statistically significant $(p=0.013)$, and the underweight and overweight BMI group was not statistically significant $(p=0.173)$.

Conclusion: Good sleep quality is more common in patients with normal BMI, whereas poor sleep quality is more common in patients with underweight and obese.

Keywords: asthma; sleep quality; body mass index

\section{PENDAHULUAN}

Asma merupakan suatu penyakit saluran pernapasan yang disebabkan karena adanya proses inflamasi kronik. Sel inflamator yang berperan pada asma khususnya adalah sel mast, eosinofil dan limfosit. Asma menyebabkan terjadinya gejala pernapasan seperti wheezing (mengi), sesak napas, dada sesak dan batuk yang terjadi terutama pada malam hari atau menjelang pagi hari ${ }^{1}$.

Di seluruh dunia diperkirakan terdapat 300 juta orang yang menderita asma dan pada tahun 2025 diperkirakan akan meningkat hingga mencapai 400 juta jiwa ${ }^{2}$. Angka kejadian asma di Jawa Tengah sebesar 4,3\%. Jumlah kasus asma di Jawa Tengah pada tahun 2013 sebesar 113.028 kasus dan kasus paling banyak terdapat di Kota Surakarta yaitu 10.393 kasus ${ }^{3}$.

Gejala asma lebih sering muncul pada malam hari atau menjelang pagi hari. Gangguan pernapasan yang muncul dapat mengganggu aktivitas tidur sehingga menyebabkan menurunnya kualitas tidur seseorang. Selain itu, gangguan pernapasan saat tidur akan semakin berat apabila seorang penderita asma memiliki Indeks Massa Tubuh yang tinggi seperti pada obesitas ${ }^{4}$.

Indeks Massa Tubuh (IMT) merupakan suatu cara sederhana yang digunakan untuk memantau status gizi orang dewasa, terutama yang berkaitan dengan kelebihan ataupun kekurangan berat badan. Di Indonesia, klasifikasi IMT dibagi menjadi kurus, normal, dan gemuk seperti yang terlihat pada tabel 1 .
Tabel 1. Klasifikasi Indeks Massa Tubuh

\begin{tabular}{lll}
\hline & \multicolumn{1}{c}{ Kategori } & Nilai IMT \\
\hline Kurus & $\begin{array}{l}\text { Kekurangan } \\
\text { BB tingkat } \\
\text { berat }\end{array}$ & $<17,0$ \\
& Kekurangan \\
& BB tingkat & $17,0-18,4$ \\
& ringan & \\
Normal & & $18,5-25,0$ \\
Gemuk & Kelebihan BB & $25,1-27,0$ \\
& tingkat ringan & \\
& Kelebihan BB & $>27,0$ \\
& tingkat berat & \\
\hline (Depkes, 2011)
\end{tabular}

Pada pasien obesitas, volume tidal menurun karena adanya penurunan ekspansi dinding dada yang disebabkan oleh berat pada dada itu sendiri dan efek obesitas abdominal pada diafragma. Pada orang yang mengalami obesitas, jaringan adiposa akan menghasilkan sejumlah sitokin dan adipokin yang memiliki efek merugikan pada saluran pernapasan serta mempengaruhi jalan napas. Beberapa sitokin tersebut diantaranya plasminogen activator inhibitor-1, monocyte chemotactic factor-1, interleukin-6 dan interleukin-8, sedangkan adipokin yang terlibat diantaranya leptin dan adiponektin. $^{5}$

Pada individu dengan obesitas, adiposit bertindak sebagai organ endokrin aktif dengan meningkatkan aktivitas inflamasi. Selain itu, adiposit dapat menambah sel-sel inflamasi lainnya dan menambah respon inflamasi. Beberapa mediator inflamasi seperti TNF- $\alpha$, interleukin-6, interleukin-18, c-reactive protein dan lainnya telah mengalami peningkatan pada pasien dengan obesitas. ${ }^{6}$

Berdasarkan teori, kategori IMT yang berpengaruh dan menjadi salah satu faktor 
risiko dari kejadian asma adalah obesitas, namun penelitian lain menyebutkan bahwa berat badan yang terlalu rendah juga dapat meningkatkan kejadian infeksi seperti ISPA (Infeksi Saluran Pernapasan Atas) yang akan menyebabkan paru-paru penderita asma mengalami peradangan dan saluran pernapasan menyempit, sehingga menyebabkan terjadinya kekambuhan asma dan penurunan kualitas tidur. $^{7}$

Efek buruk asma tidak hanya dari kelebihan berat badan namun juga bisa dari kekurangan berat badan. Hal ini terkait dengan penurunan $\mathrm{FEV}_{1}$ pada kelompok IMT rendah. Selain itu, kelompok berat badan rendah $(<18,5)$ memiliki kontrol asma yang lebih buruk dibanding berat badan normal. ${ }^{8}$ Penelitian lain menyebutkan bahwa terdapat hubungan yang signifikan antara kontrol asma dan kualitas tidur. Semakin buruk kontrol asma, maka kualitas tidur akan semakin buruk. $^{9}$

Pasien obesitas cenderung mengalami gangguan tidur dan akan berpengaruh pada penurunan kualitas tidur, sedangkan pasien dengan IMT normal akan mengalami kualitas tidur yang dominan baik karena adiposit yang berpengaruh terhadap peningkatan mediator inflamasi tidak sebanyak pada pasien asma dengan obesitas. ${ }^{10}$

Diharapkan dari hasil penelitian ini didapatkan perbedaan kualitas tidur pasien asma terkontrol sebagian pada kategori Indeks Massa Tubuh (IMT).

\section{METODE}

Penelitian ini bersifat observasional analitik dengan pendekatan cross-sectional. Penelitian dilakukan di Balai Besar Kesehatan Paru Masyarakat (BBKPM) Surakarta pada bulan Oktober - Desember 2018.

Subjek penelitian adalah pasien asma terkontrol sebagian berusia 18 tahun ke atas yang berobat di BBKPM Surakarta yang memenuhi kriteria inklusi dan tidak memenuhi kriteria eksklusi. Kriteria inklusi pada penelitian ini adalah pasien asma dewasa berumur 18 tahun keatas, pasien asma terkontrol sebagian, tidak dalam keadaan hamil dan bersedia menjadi responden, sedangkan kriteria ekslusi adalah pasien asma yang memiliki penyakit paru lain (kanker paru, pneumonia, bronkiektasis, emboli paru, dan PPOK), memiliki gangguan psikologi, mengalami insomnia dan sedang mengalami eksaserbasi. Teknik pengambilan sampel dalam penelitian ini adalah purposive sampling dengan besar sebanyak 75 sampel.

Penelitian ini dilakukan melalui wawancara terpimpin menggunakan assessment kontrol asma untuk mendapatkan pasien asma terkontrol sebagian, lalu mengumpulkan data untuk menyingkirkan kriteria eksklusi (DASS 42, IRS) dan dilanjutkan dengan pertanyaan tentang kualitas tidur (PSQI), kemudian sampel akan diukur TB dan BB untuk menghitung IMT. Data yang diperoleh berupa data nominal lalu dianalisis dengan uji Fisher's Exact Test. Pengolahan data dilakukan dengan menggunakan program aplikasi statistik (SPSS for Windows).

\section{HASIL}

Penelitian ini dilakukan pada bulan Oktober-Desember 2018 terhadap pasien asma terkontrol sebagian di BBKPM Surakarta. Total sampel yang di dapatkan adalah 75 sampel.

Tabel 2. Distribusi Sampel Berdasarkan Usia dan Jenis Kelamin ( $N=75)$

Karakteristik Frekuensi Persentase

(n) (\%)

\begin{tabular}{lll}
\hline Usia & & \\
Dewasa muda & 17 & 22,67 \\
$\quad \begin{array}{l}\text { Dewasa } \\
\text { menengah }\end{array}$ & 39 & 52,00 \\
Dewasa tua & 19 & 25,33 \\
$\quad$ Jenis Kelamin & & \\
L Laki-laki & 21 & 28,00 \\
P Perempuan & 54 & 72,00 \\
\hline
\end{tabular}


Tabel 2. menunjukkan persentase penderita asma terkontrol sebagian pada penelitian ini lebih dominan pada kategori usia dewasa menengah $(52,00 \%)$ dan sampel berdasarkan jenis kelamin lebih banyak pada perempuan $(72,00 \%)$.

Tabel 3. Distribusi Sampel Berdasarkan Pekerjaan

\begin{tabular}{lcl}
\hline \multicolumn{1}{c}{ Pekerjaan } & Frekuensi & $\begin{array}{c}\text { Persentase } \\
(\%)\end{array}$ \\
\hline Ibu Rumah Tangga & 28 & 37,33 \\
Buruh & 18 & 24,00 \\
Swasta (Fotografer, & 11 & 14,67 \\
karyawan swasta) & & \\
Mahasiswa & 4 & 5,33 \\
Pensiunan & 4 & 5,33 \\
Dosen dan PNS & 3 & 4,00 \\
Petani & 2 & 2,67 \\
Asisten Rumah & 2 & 2,67 \\
Tangga (ART) & & \\
Tukang kayu & 2 & 2,67 \\
Pedagang & 1 & 1,33 \\
\hline$\quad$ Total & 75 & 100 \\
\hline
\end{tabular}

Tabel 3. menunjukkan persentase terbesar penderita asma terkontrol sebagian pada penelitian ini jika ditinjau dari pekerjaan adalah ibu rumah tangga $(37,33 \%)$ diikuti buruh $(24,00 \%)$.
Tabel 4. Distribusi Sampel Berdasarkan Kualitas Tidur

\begin{tabular}{ccc}
\hline Kualitas Tidur & Frekuensi & Persentase (\%) \\
\hline Baik & 28 & 37,33 \\
Buruk & 47 & 62,67 \\
Total & 75 & 100 \\
\hline
\end{tabular}

Tabel 4. menunjukkan bahwa pada penelitian ini penderita asma terkontrol sebagian lebih banyak yang memiliki kualitas tidur buruk yaitu sebesar 62,67\%.

Tabel 5. Distribusi Sampel Berdarkan IMT

Indeks massa $\quad$ Frekuensi $\quad$ Persentase(\%) tubuh

\begin{tabular}{lcc}
\hline Kurus & 8 & 10,66 \\
Normal & 35 & 46,67 \\
Gemuk & 32 & 42,67 \\
Total & 75 & 100 \\
\hline
\end{tabular}

Tabel 5. menunjukkan bahwa pada penelitian ini IMT penderita asma terkontrol sebagian lebih banyak pada kategori normal yaitu sebanyak $35(46,67 \%)$ sampel dan jumlah sampel paling rendah adalah IMT dengan kategori kurus yaitu sebanyak $8(10,66 \%)$ sampel.

Tabel 6. Distribusi Kualitas Tidur Berdasarkan Usia dan Jenis Kelamin

\begin{tabular}{lcccccc}
\hline \multicolumn{1}{c}{\begin{tabular}{l} 
Usia/Jenis \\
\multicolumn{1}{c}{ Kelamin }
\end{tabular}} & \multicolumn{2}{c}{ Baik } & \multicolumn{3}{c}{ Kualitas Tidur } & \multicolumn{2}{c}{ Total } \\
& $\mathrm{n}$ & $\%$ & $\mathrm{n}$ & $\%$ & $\mathrm{~N}$ & $\%$ \\
\hline Usia & & & & & & \\
Dewasa Muda & 6 & 35,29 & 11 & 64,71 & 17 & 100 \\
$\begin{array}{l}\text { Dewasa } \\
\text { Menengah }\end{array}$ & 15 & 38,46 & 24 & 61,54 & 39 & 100 \\
$\begin{array}{l}\text { Dewasa Tua } \\
\text { Jenis Kelamin }\end{array}$ & 7 & 36,84 & 12 & 63,16 & 19 & 100 \\
Laki-laki & 7 & 42,86 & 12 & 57,14 & 21 & 100 \\
Perempuan & 19 & 35,18 & 35 & 64,82 & 54 & 100 \\
\hline
\end{tabular}

Tabel 6. menunjukkan bahwa sebagian besar sampel penderita asma terkontrol sebagian pada berbagai tingkat usia cenderung mengalami kualitas tidur yang buruk. Pada kualitas tidur berdasarkan jenis kelamin, sampel juga cenderung mengalami kualitas tidur yang buruk, baik pada laki-laki maupun perempuan, namun perempuan memiliki persentase yang lebih besar $(64,82 \%)$ 
Tabel 7. Distribusi Kualitas Tidur Berdasarkan Pekerjaan

\begin{tabular}{lrrrrrr}
\hline \multirow{2}{*}{ Pekerjaan } & \multicolumn{3}{c}{ Kualitas Tidur } & \multicolumn{2}{c}{ Total } \\
& $\mathrm{n}$ & \multicolumn{1}{c}{$\%$} & $\mathrm{n}$ & \multicolumn{1}{c}{ Buruk } & $\mathrm{N}$ & $\%$ \\
\hline IRT & 10 & 35,71 & 18 & 64,29 & 28 & 100 \\
Buruh & 5 & 27,78 & 13 & 72,22 & 18 & 100 \\
Swasta & 7 & 63,63 & 4 & 36,36 & 11 & 100 \\
Mahasiswa & 0 & 0 & 4 & 100 & 4 & 100 \\
Pensiunan & 2 & 50,00 & 2 & 50,00 & 4 & 100 \\
Dosen dan & 0 & 0 & 3 & 100 & 3 & 100 \\
PNS & & & & & & \\
Petani & 2 & 100 & 0 & 0 & 2 & 100 \\
ART & 0 & 0 & 2 & 100 & 2 & 100 \\
Tukang & 1 & 50,00 & 1 & 50,00 & 2 & 100 \\
kayu & & & & & & \\
Pedagang & 0 & 0 & 1 & 100 & 1 & 100 \\
\hline
\end{tabular}

Tabel 7. menunjukkan bahwa pada penelitian ini kualitas tidur buruk lebih banyak dialami pasien asma terkontrol sebagian yang berprofesi sebagai buruh $(72,22 \%)$ dan ibu rumah tangga $(64,29 \%)$.

Tabel 8. menunjukkan bahwa pada penelitian ini kualitas tidur buruk pasien asma terkontrol sebagian lebih dominan dialami oleh pasien dengan IMT kurus dan gemuk.
Tabel 8. Distribusi Kualitas Tidur Berdasarkan IMT

\begin{tabular}{|c|c|c|c|c|c|c|}
\hline \multirow{3}{*}{ IMT } & \multicolumn{4}{|c|}{ Kualitas Tidur } & \multirow{2}{*}{\multicolumn{2}{|c|}{ Total }} \\
\hline & \multicolumn{2}{|c|}{ Baik } & \multicolumn{2}{|c|}{ Buruk } & & \\
\hline & $\mathrm{N}$ & $\%$ & $\mathrm{n}$ & $\%$ & $\mathrm{~N}$ & $\%$ \\
\hline Kurus & 0 & 0 & 8 & 100 & 8 & 100 \\
\hline Normal & 20 & 57,14 & 15 & 42,86 & 35 & 100 \\
\hline Gemuk & 8 & 25,00 & 24 & 75,00 & 32 & 100 \\
\hline
\end{tabular}

Tabel 9. Hasil Uji Fisher's Exact Test Perbedaan Kualitas Tidur Antara IM Kurus Dan Normal

\begin{tabular}{lccccccc} 
& \multicolumn{5}{c}{ Kualitas Tidur } & \multirow{5}{*}{ P } \\
\cline { 2 - 7 } \multicolumn{1}{c}{ IMT } & \multicolumn{3}{c}{ Baik } & \multicolumn{5}{c}{ Buruk } & \\
\cline { 2 - 7 } & $\mathrm{n}$ & $\%$ & $\mathrm{~N}$ & $\%$ & $\mathrm{~N}$ & $\%$ & \\
\hline Kurus & 0 & 0 & 8 & 100 & 8 & 100 & \multirow{2}{*}{0,004} \\
Normal & 20 & 57,14 & 15 & 42,86 & 35 & 100 & \\
\hline
\end{tabular}

Tabel 9. menunjukkan bahwa dari total 8 sedangkan pada sampel dengan IMT normal, sampel dengan IMT kurus, semua sampel kualitas tidur baik lebih banyak ditemukan memiliki kualitas tidur buruk (100\%), yaitu sebesar 57,14\%.

Tabel 10. Hasil Uji Fisher's Exact Test Perbedaan Kualitas Tidur Antara IMT Normal Dan Gemuk

\begin{tabular}{lrrrrrrr}
\hline & \multicolumn{9}{c}{ Kualitas Tidur } & \multicolumn{2}{l}{ Total } & \multirow{2}{*}{ P } \\
IMT & \multicolumn{1}{c}{ Baik } & \multicolumn{2}{c}{ Buruk } & \multicolumn{2}{l}{ \% } \\
& $\mathrm{n}$ & $\%$ & $\mathrm{n}$ & $\%$ & $\mathrm{~N}$ & $\%$ & \\
\hline Normal & 20 & 57,14 & 15 & 42,86 & 35 & 100 & \multirow{2}{*}{0,013} \\
Gemuk & 8 & 25,00 & 24 & 75,00 & 32 & 100 & \\
\hline
\end{tabular}


Tabel 10. menunjukkan bahwa pasien asma terkontrol sebagian dengan IMT normal lebih banyak memiliki kualitas tidur baik $(57,14 \%)$ daripada kualitas tidur buruk
$(42,86 \%)$. Pada sampel dengan IMT gemuk, kualitas tidur buruk lebih dominan (75\%) daripada kualitas tidur baik $(25 \%)$.

Tabel 11. Hasil uji Fisher's Exact TesT perbedaan kualitas tidur antara IMT kurus dan gemuk

\begin{tabular}{lccccccc}
\hline \multirow{3}{*}{ IMT } & \multicolumn{5}{c}{ Kualitas Tidur } & \multirow{3}{*}{$\mathrm{P}$} \\
\cline { 2 - 7 } & \multicolumn{3}{c}{ Baik } & \multicolumn{3}{c}{ Buruk } & \\
\cline { 2 - 7 } & $\mathrm{n}$ & $\%$ & $\mathrm{~N}$ & $\%$ & $\mathrm{~N}$ & $\%$ & \\
\hline Kurus & 0 & 0 & 8 & 100 & 8 & 100 & \multirow{2}{*}{0,173} \\
Normal & 8 & 25,00 & 24 & 75,00 & 32 & 100 & \\
\hline
\end{tabular}


Tabel 11. menunjukkan bahwa dari total 8 sampel dengan IMT kurus, semua sampel memiliki kualitas tidur buruk (100\%). Pada sampel dengan IMT gemuk, kualitas tidur buruk lebih dominan (75\%) daripada kualitas tidur baik $(25 \%)$.

Data yang telah disebutkan diatas dianalisis secara statistik dengan uji fisher's exact test. Didapatkan 2 kelompok yang bermakna secara statistik yaitu kelompok IMT kurus dan normal serta normal dan gemuk dengan $\mathrm{p}$ berturut-turut 0,004 dan 0,013, sedangkan pada kelompok IMT kurus dan gemuk, tidak diapatkan hasil yang signifikan yaitu 0,173 . Hal ini menunjukkan bahwa terdapat perbedaan kualitas tidur pasien asma terkontrol sebagian pada kategori Indeks Massa Tubuh (IMT).

\section{PEMBAHASAN}

Penelitian yang dilakukan di poliklinik non-TB Balai Besar Kesehatan Paru Masyarakat (BBKPM) Surakarta ini bertujuan untuk mengetahui perbedaan kualitas tidur pasien asma terkontrol sebagian pada kategori Indeks Massa Tubuh (IMT). Sampel merupakan pasien asma terkontrol sebagian yang telah memenuhi kriteria inklusi dan tidak memenuhi kriteria eksklusi. Total sampel yang didapatkan berjumlah 75 orang.

Pada penelitian ini (Tabel 2), distribusi sampel asma yang tertinggi terdapat pada kelompok usia dewasa menengah (36-55 tahun) yaitu sebanyak 39 sampel dari total 75 sampel atau sebesar $52 \%$. Hasil ini sejalan dengan penelitian sebelumnya yang menjadi sumber literatur peneliti. Tingginya prevalensi asma di masyarakat menunjukkan bahwa banyak orang tua yang menderita asma dengan dampak yang terkait morbiditas dan mortalitas $^{12}$.

Distribusi sampel berdasarkan jenis kelamin menunjukkan bahwa sampel asma terkontrol sebagian lebih banyak pada perempuan dibandingkan laki-laki yaitu sebanyak $54(72 \%)$ sampel dari total 75 sampel. Pada usia dewasa kejadian asma lebih banyak terjadi pada perempuan dibandingkan laki-laki $(9,6 \%: 6,3 \%)^{13}$. Hormon ovarium pada perempuan dapat meningkatkan peradangan saluran napas yang berakibat pada kekambuhan asma ${ }^{14}$.

Pada Tabel 3. menunjukkan distribusi pasien asma terkontrol sebagian berdasarkan pekerjaan. Pada penelitian ini, pasien asma paling banyak berprofesi sebagai ibu rumah tangga yaitu sebanyak $28(37,33 \%)$ sampel dari total 75 sampel. Pada ibu rumah tangga, gejala asma dapat berkaitan dengan aktivitas membersihkan rumah dan penggunaan produk pembersih tertentu seperti pemutih, pembersih kaca, pembersih toilet, dan pewangi ruangan ${ }^{15}$. Penelitian tersebut juga menyebutkan bahwa terdapat hubungan yang signifikan antara kegiatan membersihkan rumah dan penggunaan produk pembersih khusus dengan peningkatan gejala asma ${ }^{15}$. Selain paparan agen pembersih, ditemukan fakta bahwa alergen debu dan penggunaan bahan bakar untuk memasak seperti kayu dan kotoran sapi dapat menyebabkan peradangan saluran napas dan memicu terjadinya gejala asma ${ }^{16}$.

Paparan alergen merupakan salah satu risiko terjadinya asma. Alergen yang paling sering menyebabkan asma diantaranya debu, asap, debu kayu, tepung dan isosianat. Seseorang yang bekerja dengan paparan alergen tinggi seperti buruh dan petani cenderung rentan mengalami kekambuhan asma $^{17}$.

Distribusi pasien asma terkontrol sebagian (Tabel 4) lebih banyak yang memiliki kualitas tidur buruk yaitu sebanyak 47 $(62,67 \%)$ sampel dari total 75 sampel. Penelitian lain menyebutkan, semakin buruk tingkat kontrol asma, maka kualitas tidur akan semakin buruk ${ }^{9}$. Terdapat hubungan antara penyakit asma dan gangguan tidur. Kesulitan memulai tidur, terbangun di malam hari karena sesak, bangun terlalu pagi dan kantuk di siang hari lebih sering terjadi pada penderita asma dibandingan subjek tanpa penyakit asma ${ }^{18}$. 
Indikator-indikator tersebut merupakan bagian dari kuesioner PSQI yang membuat kualitas tidur penderita asma tergolong buruk.

Tabel 5. menunjukkan pasien asma lebih dominan memiliki IMT normal dan gemuk. Asma bisa terjadi pada semua kategori indeks massa tubuh (kurus, normal dan gemuk). Berdasarkan data dari Centers for Disease Control and Prevention (2016) wanita dengan obesitas memiliki prevalensi asma yang secara signifikan lebih tinggi dibandingkan pria ${ }^{19}$. Untuk kategori normal, tidak ada perbedaan yang signifikan dalam prevalensi asma antara pria dan wanita.

Selain itu, pasien asma dengan kelebihan berat badan dan obesitas cenderung memiliki tingkat kekambuhan dan keparahan asma yang lebih tinggi. Hal ini berkaitan dengan mediator inflamasi pada obesitas seperti IL-6, TNF- $\alpha$, plasminogen activator inhibitor-1, dan lainlain. Mediator-mediator tersebut dapat mempengaruhi saluran pernapasan dan berhubungan dengan terjadinya asma ${ }^{20}$.

Pada penelitian ini, kualitas tidur buruk paling banyak dialami pasien yang berusia dewasa muda dan dewasa tua (Tabel 6.). Hal ini berlainan dengan beberapa penelitian sebelumnya yang menyatakan bahwa kebutuhan tidur menjadi berkurang pada orang yang lebih tua. Selain itu, perubahan durasi tidur, tahapan tidur, kuantitas dan kualitas tidur juga terjadi seiring bertambahnya usia ${ }^{21}$. Proses penuaan berkaitan dengan penurunan jumlah gelombang tidur lambat (slow waves sleep) dan peningkatan non-rapid eye movement (NREM) tahap 1 dan 2. Biasanya, orang pada usia dewasa menengah hingga dewasa tua cenderung tidur lebih awal di malam hari dan bangun lebih awal di pagi hari karena adanya phase advance dalam siklus tidur sirkadian normal. Disamping itu, penyakit saluran pernapasan, kardiovaskuler dan neurologi juga mempengaruhi pola tidur dan kebutuhan tidur pada orang tua, sehingga bisa berpengaruh pada kualitas tidur. Perbedaan hasil ini kemungkinan dipengaruhi oleh pekerjaan yang dimiliki pasien dengan kelompok usia dewasa muda. Pada penelitian ini, kelompok usia dewasa muda sebagian besar adalah mahasiswa dan ibu rumah tangga (IRT). Penelitian lain menyatakan bahwa hampir 60\% mahasiswa memiliki kualitas tidur yang buruk. Hal ini berkaitan dengan rutinitas di siang hari yang tidak teratur, pekerjaan sampingan, perubahan chronotype dan periode ujian $^{23}$. Selain itu, sampel pada kelompok usia dewasa muda juga banyak yang berprofesi sebagai IRT dan kaitannya dengan kualitas tidur buruk akan dijelaskan pada pembahasan selanjutnya.

Jika ditinjau dari jenis kelamin, prevalensi kualitas tidur yang buruk lebih tinggi terjadi pada wanita dan meningkat secara bertahap seiring bertambahnya usia, dan hal ini berhubungan erat dengan kejadian menopause ${ }^{24}$.

Jika dilihat dari tabel 7 , kualitas tidur buruk paling banyak dialami oleh buruh dan ibu rumah tangga. Dari total 18 sampel pasien yang beprofesi sebagai buruh, 13 diantaranya memiliki kualitas tidur yang buruk. Selain itu, dari total 28 sampel yang berprofesi sebagai ibu rumah tangga, 18 diantaranya juga memiliki kualitas tidur yang buruk.

Gangguan tidur menjadi masalah utama pada buruh atau pekerja yang mendapatkan shift malam. Pekerja shift malam memiliki kualitas tidur yang lebih buruk dibandingan dengan pekerja non-shift malam. Kualitas tidur buruk berkaitan dengan durasi tidur yang pendek dan sulit untuk memulai tidur.

Selain itu, pada penelitian ini beberapa IRT melaporkan bahwa waktu tidur mereka berkurang karena memiliki bayi atau balita. Hal ini sejalan dengan penelitian terdahulu yang melakukan penelitian di 13 negara tentang hubungan pola tidur ibu dan anak. Dari penelitian tersebut, 44,20\% IRT melaporkan bahwa pola tidur anak yang buruk sangat berdampak negatif pada tidur dan fungsi siang hari mereka yang berakibat pada kualitas tidur yang buruk ${ }^{26}$. 


\section{Analisis Fisher's Exact Test Kelompok IMT Kurus-Normal}

Pada penelitian ini (Tabel 9) didapatkan pasien asma terkontrol sebagian dengan IMT kurus lebih dominan memiliki kualitas tidur buruk yaitu sebesar $100 \%$, sedangkan pasien asma dengan IMT normal lebih banyak memiliki kualitas tidur baik yaitu sebesar 57,14\%. Hasil analisis fisher's exact test menunjukkan perbedaan kualitas tidur pasien asma terkontrol sebagian pada IMT kurus dengan normal adalah signifikan secara statistik $(\mathrm{p}=0,004)$.

Penelitian tentang pengaruh underweight terhadap kontrol asma menyatakan bahwa efek buruk asma tidak hanya dari kelebihan berat badan namun juga bisa dari kekurangan berat badan. Hal ini terkait dengan penurunan $\mathrm{FEV}_{1}$ pada kelompok IMT rendah. Selain itu, kelompok berat badan rendah $(<18,5)$ memiliki kontrol asma yang lebih buruk dibanding berat badan normal ${ }^{8}$. Penelitian lain menyebutkan bahwa terdapat hubungan yang signifikan antara kontrol asma dan kualitas tidur. Semakin buruk kontrol asma, maka kualitas tidur akan semakin buruk9 .

\section{Analisis Fisher's Exact Test Kelompok IMT Normal-Gemuk}

Tabel 10 menunjukkan bahwa pasien asma terkontrol sebagian dengan IMT normal lebih banyak memiliki kualitas tidur baik $(57,14 \%)$, sedangkan pasien asma terkontrol sebagian dengan IMT gemuk lebih dominan memiliki kualitas tidur buruk (75\%). Pada hasil uji fisher's exact test menunjukkan perbedaan kualitas tidur pasien asma terkontrol sebagian antara IMT normal dan gemuk yang secara statistik signifikan $(\mathrm{p}=0,013)$. Hasil penelitian ini sejalan dengan penelitian sebelumnya yang menyatakan bahwa kualitas tidur buruk paling banyak dialami oleh pasien asma dengan berat badan berlebih dan obesitas. Obesitas dapat menyebabkan peningkatan peradangan Th2 dan berkaitan dengan perubahan ekspresi mediator pro-inflamasi seperti leptin, IL-6, TNF- $\alpha$, protein $C$-reactive dan adiponektin yang ditunjukkan pada penderita asma dengan obesitas $^{28}$.

\section{Analisis Fisher's Exact Test Kelompok IMT Kurus-Gemuk}

Tabel 11. Menunjukkan bahwa pada pasien asma terkontrol sebagian dengan IMT kurus maupun gemuk, keduanya cenderung memiliki kualitas tidur yang buruk (berturutturut $100 \%$ dan $75 \%$ ) dan hasil analisis fisher's exact test menunjukkan perbedaan tersebut tidak signifikan secara 46nstrumen dengan $\mathrm{p}$ sebesar 0,173 . Seperti yang telah dijelaskan pada pembahasan sebelumnya, IMT kurus dan gemuk memiliki hubungan yang erat terhadap kekambuhan asma sehingga menyebabkan kualitas tidur menjadi buruk ${ }^{8}$. Hal ini sesuai dengan hasil penelitian seperti yang terlihat pada tabel 4.8-4.9 dimana pasien dengan IMT normal lebih dominan memiliki kualitas tidur baik, sedangkan IMT gemuk dan kurus dominan memiliki kualitas tidur yang buruk.

Namun, ada juga penelitian lain yang menyatakan bahwa gangguan pernapasan lebih sedikit terjadi pada pasien asma non obese (normal dan kurus) sehingga kualitas tidur pada pasien tersebut cenderung lebih baik ${ }^{27}$. Perbedaan hasil bisa dipengaruhi oleh faktorfaktor lain seperti usia, jenis kelamin, pekerjaan, dan lain-lain.

\section{SIMPULAN}

Terdapat perbedaan kualitas tidur pasien asma terkontrol sebagian pada kategori indeks massa tubuh (IMT). Kualitas tidur baik lebih banyak terjadi pada pasien dengan IMT normal, sedangkan kualitas tidur buruk lebih banyak terjadi pada pasien dengan IMT kurus dan gemuk.

\section{UCAPAN TERIMA KASIH}

Penulis menyampaikan terimakasih kepada Dr. Harsini, dr.,Sp.P (K) yang telah 
bersedia memberikan kritik dan saran terhadap penelitian ini.

\section{DAFTAR PUSTAKA}

1. Global Initiative For Asthma (GINA). Pocket guide for asthma management and prevention updated 2018. [serial online] 2018 [sitasi 10 Mei 2018]. Diambil dari : www.ginasthma.org

2. Global Initiative For Asthma (GINA). Pocket guide for asthma management and prevention updated 2011. [serial online] 2018 [sitasi 10 Mei 2018]. Diambil dari: www.ginasthma.org

3. Dinas Kesehatan. Profil Kesehatan Provinsi Jawa Tengah Tahun 2013. Semarang: Dinkes Jawa Tengah; 2014.

4. Global Initiative For Asthma (GINA). Pocket guide for asthma management and prevention updated 2012. [serial online] 2018 [sitasi 18 Mei 2018]. Diambil dari: www.ginasthma.org

5. Mohanan S, Tapp H, McWilliams A, Dulin M. Obesity and asthma: pathophysiology and implications for diagnosis and management in primary care. Exp Biol Med 2014; 239(11): 1531-1540.

6. Baruwa P, Sarmah KR. Obesity and asthma. Lung India J 2013; 30(1): 38-46.

7. Depkes. Pedoman praktis memantau status gizi orang dewasa. Jakarta: Depkes RI; 2011.

8. Furuka T, Hasegawa T, Suzuki K, Koya T, Sakagami T, Youkou A, Kagamu $\mathrm{H}$ et al. Influence of underweight on ashtma control. Allergol Int 2012; 61(3): 489-496.

9. Luyster FS, Teodorescu M, Bleecher E, Busse W, Calhoun W, Castro M, Chung KF. Sleep quality and asthma control and quality of life in non severe and severe asthma. Sleep Breath 2012; 16(4): 1129-1137.

10. Teodorescu m, Polomis DA, Gangnon RE, Fedie JE, Consens FB, Chervin RD,Teodorescu MC. Asthma control and its relationship with obestity sleep apneu (osa) in older adults. Sleep Disord; 2013: 6-8.

11. Gilman A, Douglass J A. Asthma in the elderly. Asia Pac Allergy 2012; 2(2): 101108.

12. Ilmarinen $P$, Tuomisto LE, Niemela $\mathrm{O}$, Tomnola M, Haanpaa J, Kankaanranta $\mathrm{H}$. Cluster analysis on longitudinal data of patients with adult-onset asthma. J Allergy Clin Immunol Pract 2017; 5(4): 967-978.

13. Moorman JE, Zahran H, Truman BI, Molla MT. Current asthma prevalence-united states 2006-2008. Center for Disease Control and Prevention (CDC) 2011; 60(1): 84-86.
14. Macsali F, Real FG, Omenaas ER, Bjorge L, Janson C, Franklin K, Svanes C. Oral contraception, body mass index and asthma. a cross sectional nordic-baltic population survey. J Allergy Clin Immunol 2009; 123(2): 391-397.

15. Zock JP, Vizcaya D, Le Moual N. Update on asthma and cleaners. Curr Opin Allergy Clin Immunol 2010; 10(2): 114-120.

16. Mishra LK, Verma OP. Prevalence of bronchial asthma and risk factor : a clinical study. Int J Med and Health Research 2017; 3(5): 7-9.

17. Henneberger PK, Redich CA, Callahan DB, Harber P, Lemiere C, Martin J, Tarlo SM et al. An official american thoracic society statement:work-exacerbated asthma. Am Journal Respiratory Crit Care Med 2011; 184:368-378.

18. Kieckhefer GM, Lentz MJ, Tsai SY, Ward TM. Parent- child agreement in report of nighttime respiratory symptoms and sleep distruptions and quality. Health Care $J$ Pediatr 2009; 23(5): 315-326.

19. Centers for Disease Control and Prevention. Current asthma prevalence by weight status among adults: United States, 2001-2014. US Departement of Health and Human Services; 2016.

20. Boulet LP. Asthma and obesity. Clinical Exp Allergy 2013; 43: 8-21.

21. Conte F, Arzili C, Errico BM, Giganti F, Lovino D, Ficca G .Sleep measures expressing functional uncentainty in elderlies sleep. Gerontology 2014; 60:448457.

22. Edwards BA, O’Driscol D, Ali A, Jordan AS, Trinder J, Malhotra A. Aging and sleep: physiology and pathophysiology. Semir Respir Crit Care Med.Australia: University of Melbourne; 2010: 618-633.

23. Schlarb AN, Friedrich A, Claben M. Sleep problems in universitystudents-an intervention. Neuropsychiatr Dis Treat 2017; 13: 1989-2001.

24. Madrid-Valero JJ, Martinez-Selva JM, Ribeiro D, Sanchez-Romero JF, Ordonana JR. Age and gender effects on the prevalence of poor sleep quality in the adult population. Gac Sanit 2016; 31(1):18-22.

25. Lim YC, Hoe V, Dans A, Bhoo-Pathy N. Association between night-shift work, sleep quality and metabolic syndrome. Occup Environ Med: BMJ Journal 2018; 76(1): 110.

26. Mindell JA, Sadeh A, Kwon R, Goh D . Relationship Between Child and Maternal Sleep : A developmental and cross-cultural 
comparison.

Pediatr Psychol 2015; 40(7): 689-696.

27. Singh M, Gupta N, Kumar R. Effect of obesity and metabolic syndrome on severity, quality of life, sleep quality, and inflammantory markers in patients of ashma in india. Pneumonol Allergol Pol 2016; 84(5): 258-265.

28. Lugogo NL, Bappanad D, Kraft M .Obesity, metabolic dysregulation and oxidative stress in asthma. Biochem Biophys Acta 2011;1810(11): 1120-1126.

29. Global Initiative For Asthma (GINA). Pocket guide for asthma management and prevention updated 2018. [serial online] 2018 [sitasi 10 Mei 2018]. Diambil dari : www.ginasthma.org

30. Global Initiative For Asthma (GINA). Pocket guide for asthma management and prevention updated 2011. [serial online] 2018 [sitasi 10 Mei 2018]. Diambil dari: www.ginasthma.org

31. Dinas Kesehatan. Profil Kesehatan Provinsi Jawa Tengah Tahun 2013. Semarang: Dinkes Jawa Tengah; 2014.

32. Global Initiative For Asthma (GINA). Pocket guide for asthma management and prevention updated 2012. [serial online] 2018 [sitasi 18 Mei 2018]. Diambil dari: www.ginasthma.org

33. Mohanan S, Tapp H, McWilliams A, Dulin M. Obesity and asthma: pathophysiology and implications for diagnosis and management in primary care. Exp Biol Med 2014; 239(11): 1531-1540.

34. Baruwa P, Sarmah KR. Obesity and asthma. Lung India J 2013; 30(1): 38-46.

35. Depkes. Pedoman praktis memantau status gizi orang dewasa. Jakarta: Depkes RI; 2011.

36. Furuka T, Hasegawa T, Suzuki K, Koya T, Sakagami T, Youkou A, Kagamu $\mathrm{H}$ et al. Influence of underweight on ashtma control. Allergol Int 2012; 61(3): 489-496.

37. Luyster FS, Teodorescu M, Bleecher E, Busse W, Calhoun W, Castro M, Chung KF. Sleep quality and asthma control and quality of life in non severe and severe asthma. Sleep Breath 2012; 16(4): 1129-1137.

38. Teodorescu m, Polomis DA, Gangnon RE, Fedie JE, Consens FB, Chervin RD,Teodorescu MC. Asthma control and its relationship with obestity sleep apneu (osa) in older adults. Sleep Disord; 2013: 6-8.

39. Gilman A, Douglass J A. Asthma in the elderly. Asia Pac Allergy 2012; 2(2): 101108.

40. Ilmarinen $\mathrm{P}$, Tuomisto LE, Niemela O, Tomnola M, Haanpaa J, Kankaanranta H .
Cluster analysis on longitudinal data of patients with adult-onset asthma. J Allergy Clin Immunol Pract 2017; 5(4): 967-978.

41. Moorman JE, Zahran H, Truman BI, Molla MT. Current asthma prevalence-united states 2006-2008. Center for Disease Control and Prevention (CDC) 2011; 60(1): 84-86.

42. Macsali F, Real FG, Omenaas ER, Bjorge L, Janson C, Franklin K, Svanes C. Oral contraception, body mass index and asthma. a cross sectional nordic-baltic population survey. J Allergy Clin Immunol 2009; 123(2): 391-397.

43. Zock JP, Vizcaya D, Le Moual N. Update on asthma and cleaners. Curr Opin Allergy Clin Immunol 2010; 10(2): 114-120.

44. Mishra LK, Verma OP. Prevalence of bronchial asthma and risk factor : a clinical study. Int J Med and Health Research 2017; 3(5): 7-9.

45. Henneberger PK, Redich CA, Callahan DB, Harber P, Lemiere C, Martin J, Tarlo SM et al. An official american thoracic society statement:work-exacerbated asthma. Am Journal Respiratory Crit Care Med 2011; 184:368-378.

46. Kieckhefer GM, Lentz MJ, Tsai SY, Ward TM. Parent- child agreement in report of nighttime respiratory symptoms and sleep distruptions and quality. Health Care $J$ Pediatr 2009; 23(5): 315-326.

47. Centers for Disease Control and Prevention. Current asthma prevalence by weight status among adults: United States, 2001-2014. US Departement of Health and Human Services; 2016.

48. Boulet LP. Asthma and obesity. Clinical Exp Allergy 2013; 43: 8-21.

49. Conte F, Arzili C, Errico BM, Giganti F, Lovino D, Ficca G .Sleep measures expressing functional uncentainty in elderlies sleep. Gerontology 2014; 60:448457.

50. Edwards BA, O’Driscol D, Ali A, Jordan AS, Trinder J, Malhotra A. Aging and sleep: physiology and pathophysiology. Semir Respir Crit Care Med.Australia: University of Melbourne; 2010: 618-633.

51. Schlarb AN, Friedrich A, Claben M. Sleep problems in universitystudents-an intervention. Neuropsychiatr Dis Treat 2017; 13: 1989-2001.

52. Madrid-Valero JJ, Martinez-Selva JM, Ribeiro D, Sanchez-Romero JF, Ordonana JR. Age and gender effects on the prevalence of poor sleep quality in the adult population. Gac Sanit 2016; 31(1):18-22. 
53. Lim YC, Hoe V, Dans A, Bhoo-Pathy N. Association between night-shift work, sleep quality and metabolic syndrome. Occup Environ Med: BMJ Journal 2018; 76(1): 110 .

54. Mindell JA, Sadeh A, Kwon R, Goh D . Relationship Between Child and Maternal Sleep : A developmental and cross-cultural comparison.

Pediatr Psychol 2015; 40(7): 689-696.

55. Singh M, Gupta N, Kumar R. Effect of obesity and metabolic syndrome on severity, quality of life, sleep quality, and inflammantory markers in patients of ashma in india. Pneumonol Allergol Pol 2016; 84(5): 258-265.

56. Lugogo NL, Bappanad D, Kraft M .Obesity, metabolic dysregulation and oxidative stress in asthma. Biochem Biophys Acta 2011;1810(11):1120-1126 